\title{
APPOINTMENT OF JUDGES
}

\author{
W. H. HURLBURT, Q.C.*
}

Mr. Hurlburt recognizes that our system of judicial appointment is open to public criticism in that even well-disposed persons infer that partisan political factors are considered to play the predominant role in appointments. He analyzes the Canadian Bar Association proposal and after concluding that it is unsatisfactory, proceeds to put forth and defend, a viable remedy based on the Canadian Judicature Society Plan.

What lawyer is there, who doesn't wince at the view of the public that his political interests were coterminous with his interest for himself? The public think that sneer is backed with truth. Such a state of things degrades the profession, and, if continued, must impair and weaken the authority of the Bench. ${ }^{1}$

The public interest requires that appointments to the Bench be demonstrably based on merit, and upon merit alone. It requires a system of appointments which will give effect to this proposition.

Canadians have enjoyed over the years, and still enjoy, a Bench composed in the main of Judges of integrity and capacity. We have done much better than we deserve. Among ourselves, we may make sufficiently bold to say our good fortune results from the high standards of integrity and capacity of the legal profession generally.

However, it is not enough today to tell the public that appointments are generally good, nor is it enough to tell them that in the main the Bench is composed of Judges of integrity and capacity. The public are increasingly inquisitive about the processes of our various institutions of government and of the institutions involved in the administration of justice; this is good. However, people are increasingly sceptical about what they are told. The increased scepticism and disillusionment are not good; they undermine the rule of law, which can be maintained only while people in general have confidence in the system and the institutions by which it is maintained. Any significant reduction in that confidence is a threat to our freedoms; any significant accession to that confidence strengthens them.

Justice must not only be done, but it must also be seen to be done. This statement seems trite because it has been said so often, but it has been said so often only because it lays down a fundamental principle which cannot be ignored in any aspect of the administration of justice if the system is to command the necessary public confidence. That the appointment of Judges is a fundamental part of the administration of justice is obvious; that justice will be seen to be done only if judicial appointments are seen to be properly made seems to be equally obvious, and to be borne out by experience. Appointments will be seen to be properly made only if they are made through a system directed towards the appointment of the persons best fitted for the Bench.

Needless to say, lawyers have a vested interest in the legal system. Having invested years of our lives in the legal system we inevitably have

* B.A., LL.B. (Alta), of the Edmonton firm of Hurlburt, Reynolds, Stevenson, and Agrios.

1 Honourable Wallace Nesbitt. Sometime Justice of the Supreme Court of Canada, Presidential Address to the Canadian Bar Association, 1929, 14 Proceedings of the Can. B. Assoc., 99. 
strong feelings of respect for it and for the great traditions upon which it is founded. These are not, it is submitted, reasons for taking the position that the system has no defects; they are reasons for us to do what we can to see that the system deserves our respect and the respect of the public generally. They are reasons why we should do everything in our power to make it impossible for any reasonable person to justify a slur upon the system. There are other reasons as well: being favoured by the existing social structure, we have a duty to make use of our favoured position to advance the general interest; and as members of the public we have a vital interest in the rule of law.

\section{II}

The Minister of Justice bears the responsibility for appointments to the Bench. From time to time he announces the making of appointments. He does not disclose the procedures which have been gone through in order to decide upon the person appointed. A large proportion of the appointments made by each administration have involved persons associated with the political party from whom the administration is formed. From these facts, even well-disposed persons infer that partisan political factors have been considered in making the appointments. Ill-disposed persons go on to draw the further inference that it is the partisan political considerations which dictate the choice and not the considerations of individual merit which most lawyers would point to as the governing consideration. Most lawyers must, at some time, have found themselves in the intolerable position of having this further inference stated as fact, without having the means of satisfactory rebuttal at hand. The only satisfactory rebuttal would be that the appointment was made after a procedure had been gone through demonstrably designed to result in the appointment of the person best suited to the position at the time and place involved. As matters now stand, it cannot be said why a particular appointment is made nor can it be said who suggested it, and so we are not able to deal with the statement as it deserves.

By way of example, a letter was received by a newspaper which at the time was publishing a column relating to legal matters. The internal evidence is that the writer was a decent and responsible person employed in the category of a skilled labourer. He wrote:

Among a group such as this discussions take place on many subjects. This includes many aspects of the law. It is agreed that the Federal Government through the Minister of Justice appoints all Judges and the Provincial Government through the Attorney General appoints all magistrates, each level of government paying the salaries of their own appointees. The main qualification in all appointments being political. There the agreement ends, by a majority of 14 to 1 (I'm the one). It is said that, in effect "he who pays the piper calls the tune." In effect if you are a good active Liberal or known supporter you get preferred treatment at the hands of a judge and if a good S.C. you get the same at the hands of a magistrate.

This sort of feeling is far too common. Press reports make a point of stressing political connections when appointments are announced. Articles and periodicals make similar points. Editorials are written. Labour unions refer to Judges who make unpopular decisions as "political hacks." The feeling affects the well-disposed majority only because jus- 
tice is not seen to be done, because judicial appointments are not seen to be made on grounds of merit alone.

The general impression is that lawyers strive for judicial appointments, and that they engage in political activity in the hope of obtaining judicial appointments. The legal profession is not in fact that venal, but in trying to persuade the public of this we are, under the circumstances, understandably suspect.

The tragedy is that the usefulness of the finest Judges is seriously diminished. Many of the public think that these men were not appointed because of their merit, and that, in fact, they have probably engaged in practices which would detract from their merit. Even lawyers will often mention an appointment and follow in the next breath with some cynical statement relating to the reasons for the appointment. These attitudes seep out into the public consciousness and they affect the public view of the courts and of the administration of justice.

A judge, by the nature of his position, is at the heart of controversy. A disappointed litigant or convicted person will inevitably look for someone to blame for what he sees as injustice. If he can look farther than his lawyer, he is very likely to look to the judge. The easiest form of rationalization is that the judge must have been dishonest. This type of rationalization feeds upon the circumstance that the method of appointment has no obvious safeguard against the making of appointments for partisan political reasons.

The problem is well and succintly put by Mr. J. T. Weir, the President of the Canadian Bar Association, 1966:

Canada has taken great pride in her judges in the past, and the public confidence they enjoyed has been a major stabilizing force in our society. We have been assuming, and not without good reason, that every accused and every litigant has had faith in our judges' impartiality and competence.

This has been expressed in Section 2(2) of the Association's Canons of Ethics, in part as follows:

'(2) Judges, not being free to defend themselves, are entitled to receive the support of the Bar against unjust criticism and complaint.'

However, in recent years there has been a trend towards reduction in public confidence which must be arrested and the old opinion restored.

\section{III}

Unlike almost anyone else who discusses the constitution these days, I am not suggesting a change in it. The elected political authority must ultimately control the appointment of Judges. It is not beyond human ingenuity, however, to devise a system which, without interfering with the executive power of appointment, will be consistent with the traditions upon which the administration of Canadian justice is based.

Faced with a somewhat similar problem, it appears that the English have adopted a particularly English solution. They have simply decided that appointments would not be based on partisan political considerations and the appointing authorities by their actions have made it clear that the decision has been adhered to. There are very definite problems in Canada which do not exist in England, and it is doubtful that the same solution would work here. For one thing, the English Lord Chancellor is by tradition a barrister who knows the English Bar personally and by reputation; it is impossible for the Minister of Justice to have a similar knowledge of the Bar of Canada. For another, the English are not faced 
with the problems which are the other side of the strength arising from our rich cultural and ethnic diversity. It should be noted that there is no particular reason to think that political activity on the part of the English barristers has noticeably declined by reason of the system adopted.

Various solutions have been adopted in various areas of activity in the United States. That country, however, has a constitution quite different from ours and these differences have to be borne in mind.

A committee of the American Bar Association functions in the area of appointment of Federal Judges. Particularly where Senate confirmation is involved, the system has had some success.

A more fundamental type of reform adopted by some of the American states involves a non-partisan nominating committee. Originally advanced by the American Judicature Society, this plan was approved by the American Bar Association in 1937. Since the same proposal is at the heart of the proposal to be made by this paper, it will not be discussed further at this point. Suffice it to say that this basic idea has been successful.

The Commission on Law Enforcement and the Administration of Justice appointed by the President of the United States had this to say:

In general, the Commission favors the appointive method for the selection of judges over the elective method, although it recognizes that in some special situations the elective method presents advantages, especially in diverse urban communities where the election of judges may insure that all groups in the community are represented in the judiciary. The Commission believes that far more important than the choice between elective and appointive systems, however, is the existence in the selection system of an effective procedure for the screening of potential candidates for the judiciary on the basis of their personal and professional qualifications for office. The group that performs this screening function should be established by law, should be directly responsible to the appointing authority, and should be carefully selected to insure that its membership is representative and is not drawn from an unduly narrow segment of the bar or the community.

The Commission believes that the best selection system for judges is a merit selection plan generally of the type used successfully in Missouri for some 25 years, and long supported in principle by the American Bar Association and the American Judicature Society. The Missouri type plan is now in use with a number of variations in some 10 states. Its basic approach is also embodied in the procedures used by the mayor of the city of New York to appoint criminal court judges. The Missouri plan is characterized by four elements:

1. The nomination of a panel of judicial candidates by a nonpartisan commission composed of conscientious, qualified laymen and lawyers.

2. The requirement that the executive appoint judges only from the panel submitted by the commission. ....2

And the Christian Science Monitor, concluding a notable study of the administration of justice in the United States, had this to say about what legislatures can do:

Take judges out of politics-even if it requires a referendum and/or constitutional amendment. Nomination of judges by a blue-ribbon commission and appointment by the governor is usually considered the best solution. ${ }^{3}$

IV

A recent step has been taken with the intention of improving the system of appointments in Canada. The Canadian Bar Association has set up a National Committee on the Judiciary which is established "for the purpose of assisting the Minister of Justice in the exercise of his authority

2 The Challenge of Crime in a Free Society; A Report by the President's Commission on Law Enforcement and Administration of Justice, United States Government Printing Office, February 1967, p. 146.

8 Christian Science Monitor, July 5, 1967 at 9. 
and responsibility to make appointments to the judiciary by considering and expressing opinions on the suitability and qualifications of persons being considered by the Minister of Justice for judicial appointment." The Minister of Justice has agreed to refer names to this committee, and appears to be following this procedure.

Unfortunately, this step does not (in my submission) go to the root of the problem.

The main reasons that the present system derogates from the respect in which the judiciary should be held by the people are first, that appointments are made under a system which is not demonstrably directed toward appointment of the best men available, and, secondly, that appointments are made to a great extent from persons of the same political colour as the administration. While the National Committee on the judiciary will no doubt perform a useful function, it does not seem that it will deal with either of these problems for the following reasons:

1. The Committee does not initiate names; it can do no more than register objection to an unsuitable appointment. There will be nothing to show that there is real change, because the initial selection of the name will be made under the same system. There is no built-in safeguard against selection for partisan political reasons.

2. The composition of the Committee (two from each of the Maritimes, Ontario, Quebec and the Prairies, and one from British Columbia) makes it appear likely that any opinion will be that of one or two men; a Maritime or Ontario representative is not likely to be able to express a helpful opinion concerning a Prairie lawyer. Further, there is no reason to believe that the Committee is likely to be representative of the Bar actively practising before the Courts. If the public is of the view that political pressure is exerted on one man, the Minister of Justice, it is not likely that they will be satisfied with the addition of a voice which appears likely to be the voice of only one or two other men, who remain in their position for a long period of time.

3. There is nothing to show in any individual case that the Minister is guided by the advice which he receives. This objection could be got around if the Minister would agree to accept an adverse opinion. The Minister, however, has said:

Again, to the best of my memory, I have made no appointment of a person which had met with the disapproval of this committee.

That does not mean I am bound to continue in this direction.4

4. There is no indication that the opinion asked for will be an opinion as to whether the person named is the most suitable person; the most that is called for is an opinion of the individual as such, without any provision for comparison with other available persons. The way it is put by the Minister is:

My policy is to go to this particular committee of the Canadian Bar Association and say: I am thinking of appointing so-and-so; I should like to know whether in your opinion he is qualified.

The Minister has expressed the result of his consultation as follows:

The members of this committee have been extremely helpful to me in making sure that any person I have named at least did not have a black mark against him with the bar. ${ }^{8}$

4112 Hansard, p. 4896 (November 30th, 1967).

5 Ibid.

Ibld. 
It would be difficult to say of any lawyer who has been in active practice for any length of time that he is not "qualified" to be a judge, or that he has "a black mark against him with the bar," unless his reputation is very bad. There is no reason, for example, to think that this system would have avoided the appointment of the judge who recently resigned after hearings before a Royal Commission and a Parliamentary Committee. The fact that the National Committee on the Judicary is not looking for the best man would appear to be one of the fundamental reasons why this system will not in the long run inspire trust.

5. There seems to be no reason why the public should place more trust in the result of the unseen workings of the organized legal profession than it places in the unseen workings of the Cabinet.

For these reasons it is suggested that the Canadian Bar proposal, while well intentioned and no doubt useful in itself, will not solve the problem. Further, it actually serves to postpone thought-about reforms which are urgently needed if the judicial system is to stand the test of these very difficult times.

\section{V}

It is now time to make a positive suggestion. This will relate only to the Provincial Courts. While the same basic principles should apply to the Federal Courts, some of the problems are different and it is beyond the scope of this paper to deal with federal courts.

The system of appointment should proceed upon the following basic principles:

1. Suggestions for appointment to the Bench should come from a source which can be demonstrated to be as free as possible of partisan political considerations.

2. The criterion should be that of the most suitable man for the appointment.

3. It should be made apparent that each appointment results from extensive investigations of the possible choices.

4. The ultimate responsibility should remain with the executive authority.

It is often said that it is not possible to constitute a group which is not subject to political pressure, either of the usual kind or of a kind generated by the existence of the group itself. However, experience elsewhere has shown that such a group can be constituted and can function and I do not think that it is beyond human ingenuity to create a Commission in each province which would be up to the necessary standard. It is difficult in a paper of this kind to avoid, on the one hand, the charge of failing to produce a concrete proposal, and the problem, on the other, of exposing the whole idea to criticism because a detail of the concrete proposal is open to criticism. However, the Canadian Judicature Society, a lawyers' group, has developed a plan which is here advanced. The Commission in each Province could consist of the Chief Justice of the Province or a Judge appointed by him, as Chairman; two persons appointed by the Attorney General of the Province, at least one of whom should not be a lawyer; two persons appointed by the Federal Government, at least one of whom should not be a lawyer; and one member of the Law Society of the Province concerned, either appointed by the 
governing body or elected by the members in the same manner as the governing body. With the exception of the Judicial member of the Commission, it would be desirable to limit terms to two years, and to have a rotation system of retirement. Members of the Commission would have to agree not to be eligible for judicial appointment while serving on the Commission or for some reasonable time, such as five years, afterwards. The plan, however, does not stand or fall with the specific suggestions as to the personnel of the Commission which can be varied so long as the basic principle of an independent and non-partisan source is maintained.

This Commission, having some sort of continuous existence, would be in a position to consider the whole matter at leisure and to make continuous and sustained investigations and inquiries. These would be carried out in private and the Commission would be in a position to furnish a name, or a group of names, whenever a vacancy became available. The nominations themselves would not be public, but the Minister, in announcing the nomination, would be able to say that he had accepted a nomination by the Provincial nominating commission.

It will be seen that the suggested Commission would be constituted in such a way that no one authority, even if it chose to attempt to influence the result, could have control. The suggestion that nominees of the Attorney General be included is based upon the constitutional responsibility of the Attorney General for the administration of justice in the Province. It will be seen that the legal profession, on the Judicial and practicing side, would probably constitute a majority but there would be lay participation, and the organized profession would not dominate the Commission. It should be emphasized again, however, that the proposal here advanced should not stand or fall with the detailed suggestions as to membership of the Commission.

The Commission would not have any constitutional or formal authority, but would require the informal agreement of the government that the Minister of Justice would consult with and follow the advice of the Commission, the Governor General in Council retaining always the power to make appointments and to refuse to accept the advice of the Commission if it should conclude that the Commission is not functioning in a proper manner.

\section{VI}

A number of the customary rejoinders to any such proposal must be considered.

The proposed Commission would not trench upon the constitutional authority of the Cabinet. The Cabinet, while retaining the ultimate authority, since there must be an ultimate authority, could suitably follow a system under which they would accept nominations coming from an independent source, leaving themselves perfectly free to reject all or any of those nominations in a proper case. Ultimate authority would be retained, but it would be exercised so that justice would be seen to be done. The Minister has said this:

However, I am not too concerned about the political past of the appointee. If he is a good person and is qualified for the bench, then these are sufficient qualifications and they are the ones that are uppermost in my mind. It has 
happened on occasion that I discovered post facto that a certain appointee was of such and such a political persuasion, but this is not the most relevant consideration in $\mathrm{my}$ choice. ${ }^{7}$

The sole purpose of the proposal is to satisfy a sceptical and inquisitive public that what the Minister says is true, and to satisfy them also that the information upon which he acts is the best and most complete information which can be obtained and not merely information received from partisan sources. It should be noted that there would be nothing in the proposal to prevent the Minister from forwarding to the Commission the names of any persons he thinks suitable for appointment.

There is nothing in the proposal which would prevent a Provincial Commission or the Minister or the Cabinet from recognizing the fact that considerations of geography, cultural background, etc., raise different problems in different places, and the further fact that it may be advantageous in providing for the administration of justice in a multicultured nation to take advantage of the diverse cultures.

Then there is the statement so often made, but so far removed from the facts as almost to defy objective discussion, that a reformed system will in some way prevent, or at least militate against, the appointment of persons active in politics. The short answer to this argument is that it will not do so unless persons active in politics are less worthy of appointment than others, which is not a proposition which should commend itself to proponents of the present system. In fact, the proposed system would make it possible to appoint members of political parties other than the party from which the administration of the day is drawn, and it would make it possible to appoint persons who have distinguished themselves in municipal politics. The search will be for men of ability and integrity. Men who have demonstrated these qualities in public life will inevitably have an advantage.

Finally, it may be said that the proposal is impractical because the "facts of life"-a cynical phrase, which implies acceptance of the truth of what is alleged against the present system-will make it unacceptable. The same statement has been made in England and the United States. Faced with informed opinion in the legal profession and the public, changes have been made elsewhere. Similar changes can be made here. It is the duty of those who agree with the proposition that the public interest requires that judicial appointments be demonstrably based on merit and upon merit alone to see that this opinion is borne in upon those who have the power.

\section{VII}

During our active lives we, as lawyers, are the guardians of the great traditions handed down from the past. It is our obligation to see that these traditions are not, in the changing conditions in which we find ourselves, stultified through failure to make proper and appropriate changes in them.

The fundamental submission made by this paper is that we should constantly examine our institutions in the light of the needs and demands of the times in which we find ourselves; that if we find that the funda-

7 Ibld. 
mental values embodied in institutions can best be preserved by a change which does not conflict with those values we should make that change; and that the adoption of a system of appointment of judges from nominations by an independent Commission, subject to the ultimate authority of the appointing power, is a change which is required if our judicial institutions are to preserve the values upon which they are based. 